\title{
ACHIEVING SUSTAINABLE URBANIZATION OF THE NATIONAL THEATRE IN LONDON THROUGH CHANGE OF USE AND FUNCTIONS OF ARCHITECTURE
}

Scientific paper

(Received: 26 March 2021; accepted: 29 September 2021)

\section{Danijela Rogina}

Josip Juraj Strossmayer University of Osijek, Faculty of Civil Engineering and Architecture Osijek

Corresponding author: drogina@gfos.hr

\section{Radivoje Dinulović}

Faculty of Technical Sciences, University of Novi Sad, Professor

\begin{abstract}
The human population is currently on the rise and most Europeans live in urban areas, leading to increased urbanization. The change comes with its challenges, as cities, architecture, and urban spaces need to become more fluid, multi-functional, and innovative. This paper examines whether a change of use of public spaces, and functions of architectural and urban forms, can be used as an element in the implementation of sustainable urbanization. The theoretical framework of this paper focuses on literature findings relating to identified key aspects such as innovative approaches in changes of use - recycling and upcycling, green infrastructure and financial aspects, concepts of "right of the place", and public participation. These aspects are addressed on both theoretical and practical levels, with the National Theatre in London as a case study. Findings convey that the change of use of spaces can be utilized to achieve sustainable urbanization, together with the management of functions and uses of architectural and urban forms. However, further research is needed with various stakeholders to identify a solid and inherent database, as a foundation on which the most optimal urban spaces would emerge, by identifying new functions and uses of urban space and architecture.
\end{abstract}

Keywords: Change of use; sustainability; urbanization; functions of architecture; public space. 
Achieving sustainable urbanization of the National Theatre in London through change of use and functions of architecture

\section{INTRODUCTION}

Urban forms started with the emergence of the cities, and were always susceptible to change and transition, due to being a complex phenomenon that includes technological, economic, social and political aspects [1]. Urban form at its core contains architecture, which, among various other manifestations, can present itself as a broad cultural movement [2], and when discussed and criticized outside the narrow circle of specialists, first becomes a part of the city and subsequently, itself becomes that "city". This is yet another feature and potential of architecture which, if successfully achieved, can contain various harmonized social and economic concepts of modern society. For this paper, architecture will be studied through its ability to operate within both economic and social constraints [3]. Crawford (1991) pointed out that there is a certain polarity and opposition between actual practices and ideological representations, between multi-utility or actual uses, and ideology or multi-functioning of architecture. These two aspects will be considered as a dichotomy. The first one being the aspect of architectural utilitarian use; for example, a theatre building can function as a theatre, gallery, bookstore, or a café. The other aspect of this dichotomy is an architectural ideological function [4]. Such functions can be educational, economic, commercial, cultural, political, inspirational, environment-related, nostalgic-romantic, social, touristic, culinary or promotional - to list but a few out of an inexhaustible range of architectural functions, in order to outline the various possibilities in the case of the National Theatre in London. This paper explores and proves that the change of use of public space and urban forms, as well as management of their functions, are a valuable tool when trying to achieve sustainable urbanization, driven by the individual. It combines several research techniques, including the case study, which is considered to be a method of empirical research that explores in detail the contemporary phenomenon - the "case" - within its real context, and thus contributes to its understanding and awareness of potential implications [5].

For the analysis of the case study presented in this paper, the National Theatre in London, Great Britain, was chosen to illustrate a real-life example of a successful implementation of multi-functional architecture and uses of space, as well as offer a better insight into the global state of the functions of architecture and highlight this particular example of excellence.

\section{ARCHITECTURE AND URBANIZATION}

If it is considered that architecture does not touch art and life through the creation of scene or spectacle but the program [4] while each program contains many functions, then it can be understood better why architecture can have many functions. Functions of architecture are various, simultaneous, and at times very different, but not exclusive and, therefore, architecture can be considered as a movement.

When trying to create socially balanced and sustainable urban spaces, the social function of architecture is particularly important. Ward [6] says that social architecture is an instrument for progressive social change, because it prioritizes the increase of human dignity and reduces human suffering. He says that architecture is "nothing but social", yet its social practice has both supported and reinforced existing social hierarchies, and operated mostly as a mechanism of oppression and domination. Ward further states that social architecture challenges structures of domination, and calls capitalism itself into question as he creates a sound premise that architecture has always been strongly entangled with power and politics. Through this symbiosis, architecture leaves an undeniable mark in any urban, public space.

Rogina, D, Dinulović, $R$ 
Achieving sustainable urbanization of the National Theatre in London through change of use and functions of architecture

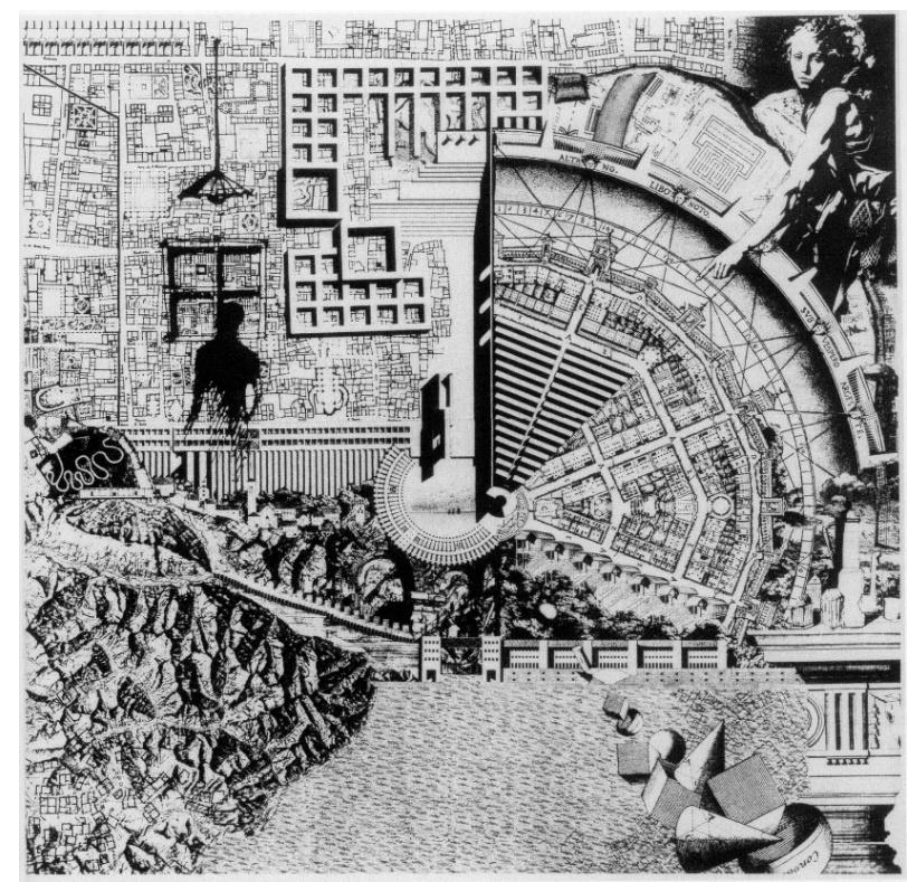

Figure 1 "The Analogue City" at the Biennale of Venice, 1976 [7]

The figure above represents a metaphorical method for understanding and designing the city. "The Analogous City" (La Città Analoga), Fig. 1, confronts reality, memory, and imagination. It is a collage of the real and the ideal, the historical and the fictional, where Rossi used a painting of Canaletto with an imaginary Venice to describe his method. Rossi [2] once proclaimed that he did not invent, but he remembered, and what he meant was that the new contains something old within itself, that perhaps there is nothing so new and original that can be created without owing something to past achievements and ideas. He claimed that the city itself is the collective memory of its people and like memory, it is associated with objects and places; therefore, he states that the city is the locus of the collective memory. He said that the city's predominant image is based on the relationship between the locus and the citizenry, architecture and landscape, and as certain elements become part of its memory, new ones begin to emerge. According to Rossi [2], the memory becomes the guiding thread of the entire urban structure in its complexity, as the locus becomes the primary attribute of the city of collective memory and for that memory to be relevant and preserved, changes of use of spaces need to occur. Through the change of use of space as well as functions, cities can thrive and evolve, together with their inhabitants. Yates [8] interprets further, that memory attaches itself to certain spatial structures or the specific concept of urbanization, and it can be added that memories attach themselves to the city as well.

This brings us to the question: What is urbanization? Urbanization is a complex socio-economic process that, according to the United Nations (UN) [9], transforms the built environment with initially rural features into urban settlements, while performing the spatial redistribution of the population from rural to urban areas. It involves changes in dominant occupations, lifestyles, culture and behaviors and thus changes the demographic and social structure of urban and rural areas. Urbanization is shaped by spatial and urban planning, as well as public and private investments in buildings and infrastructure, and refers to both an increase in the percentage of the population living in urban areas and the size of cities [9].

At the heart of the concept of urbanization, the process of migration of people can be observed, from nature settings and rural areas to urban environments, which indicates the evolutionary connection of man and nature. There are two key and opposing views on the notion of urbanization concerning nature: Urbanization that destroys nature and poses a threat [10], and urbanization as a shelter and refuge in which people seek protection and security from the extreme effects of climate, nature, and the environment [11]. Following the migration of the world's population to cities, urban dwellers began to miss nature. Interventions in urban spaces that represented green initiatives soon developed into green infrastructure $(\mathrm{GI})$. This, now a legitimate part of the urban landscape, brought Rogina, D, Dinulović, R 
Achieving sustainable urbanization of the National Theatre in London through change of use and functions of architecture

about a new type of architecture-Eco-oriented architecture, which can be considered one of the key functions of the humanization of the urban environment [12].

Cities started experiencing changes of use of many public and urban spaces, as the regulations and directives formalized and defined GI, with documents such as Green Infrastructure and Territorial Cohesion [13] or World Urbanization Prospects [9]. However, like in all urban development, the financial aspect is very important, especially because the $\mathrm{GI}$ type of investment can be linked to profit after investment. Often, significant financial investment in creating $\mathrm{Gl}$ is considered to be an aggravating circumstance in the attempts to increase the number of $\mathrm{Gl}$ in urban areas. Generally, changes come at a price-including financial changes; however, changes of use regarding the space of architecture or functions do not need to be costly in all cases. For example, scientific evidence has already been seen, during the creation of $\mathrm{Gl}$ in urban areas, that it can be achieved with a frugal or even non-existent budget. Herman et al. [14] surveyed three parks in Faro, Portugal and illustrated how low-budget strategies and the limited use of funds and resources can result in successful public Gl projects, with successful changes in the use and functions of public spaces and architecture. This leads us to the key questions that this paper raises: Can the change of use of public spaces and architecture serve as a tool for the implementation of sustainable urbanization? Can sustainable urbanization be achieved through the management of functions of architectural and urban forms?

\subsection{Mega-Cities as a Concept of the Future of Urbanization}

Today, most Europeans live in urban areas and, according to the harmonized definition of Eurostat and the OECD, urban areas-defined as cities, towns, and suburbs-provide a home to $72 \%$ of the EU population. Out of that number, $41 \%$ live in cities and $31 \%$ in cities and suburbs, and the concept of mega-urban settlements is growing and becoming more common [15]. According to a UN report [9], almost half of the world's urban dwellers reside in settlements with fewer than 500,000 inhabitants, while around one in eight lives in 33 megacities with more than 10 million inhabitants. The world is projected to have 43 megacities by 2030 [9]. This redistribution of the population will not come without a price. One of the main issues relating to increased urbanization is that cities consume 60$80 \%$ of primary energy and $60-80 \%$ of natural resources, while producing $50 \%$ of global waste and $75 \%$ of greenhouse gas emissions [16]. Therefore, it is particularly important that urban spaces, as well as architecture itself, have a range of positive, desirable, and efficient functions and uses, which complement, intertwine, and create a multi-functional network of various public spaces, a characteristic that is traditionally desirable in the case of the successful architectural and urban environment.

\section{MULTIFUNCTIONALITY AND USES OF ARCHITECTURAL FORMS, URBAN AND PUBLIC SPACES ON THE EXAMPLE OF THE NATIONAL THEATRE IN LONDON}

Urban planning or Town Planning is a professional and political process that deals with the development and design of land use and the built environment, including air, water, and infrastructure passing in and out of urban areas, such as the transport, communication, and distribution network [17]. Among the various types of land and space use, there are also temporary uses that have become an established tool in European cities for the reactivation of vacant or derelict spaces, providing financially disadvantaged users with additional space. They can be a real winwin situation for users, owners, and authorities if the interests of different stakeholders are taken into account and tailored to low-budget investments [18]. Abandoned and neglected spaces, just like architectural forms in the same state, the so-called "architectural leftovers" [19], appear in almost all urban areas, whilst beginning to function as depressive, destructive, and antisocial elements or spaces of the urban environment.

Ziehl and Oßvald [18] discussed possible scenarios for the adaptation of neglected buildings and "brownfield" land, that is, spaces using the terms "second-hand spaces" or "used spaces", which are often found in the domain of temporary uses. This concept emphasizes the sustainable effects of temporary use on urban development, and alternative practices such as space sharing, do-it-yourself interventions, collective self-organization, recycling or upcycling. Spaces are renovated, reused, re-discovered with the minimal use of new resources, turning them into places with new and improved functions, greater value, better quality, and benefits for the community.

Rogina, D, Dinulović, $R$ 
Achieving sustainable urbanization of the National Theatre in London through change of use and functions of architecture

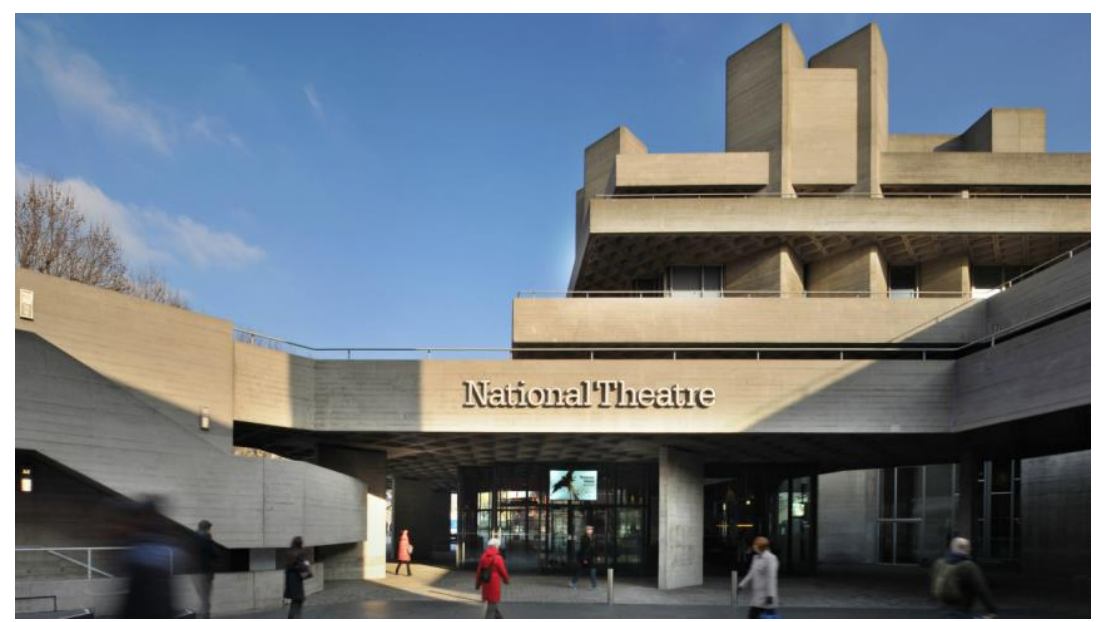

Figure 2 The National Theatre in London [20]

Regarding the key example in this paper of the building of the National Theatre, Great Britain, Fig. 2, the multifunctionality of its architecture, space, and uses-in a utilitarian sense-is illustrated. Through the creative and clever use of interior and exterior space, this example shows us how architecture, in its most essential form, can have a successful impact on public space, while increasing the quality of the entire urban environment. The interior itself includes spaces with various functions; therefore, in addition to the utility-related uses-theatre and concert halls, galleries, lounges and cafés-this building prides itself on numerous ideological or environmentally sustainable functions.

\subsection{Utilitarian use of space and architecture}

The National Theatre is vast and city-like as a structure designed in 1976 by the eminent, British architect Denys Lasdun (1914-2001) with the idea of architecture as an urban landscape. It stands on the South Bank of the River Thames and is formed from two fly towers rising from layered horizontal terraces that wrap around the building, cascading to the river level. It accommodates three theaters, the largest seating 1,160 people, alongside restaurants, bars, foyers, workshops, and all the necessary mechanisms and the opportunity to see live events behind the scenes. There is free wireless internet access and digitized content about the history of the institution throughout the building. Lyttelton Lounge includes the best offer of digital content that is constantly evolving and provides a free mobile phone application. Sherling Backstage is open to the public, with backstage access that provides visitors with a direct view of busy production workshops, giving them the opportunity for individual experience. 
Achieving sustainable urbanization of the National Theatre in London through change of use and functions of architecture

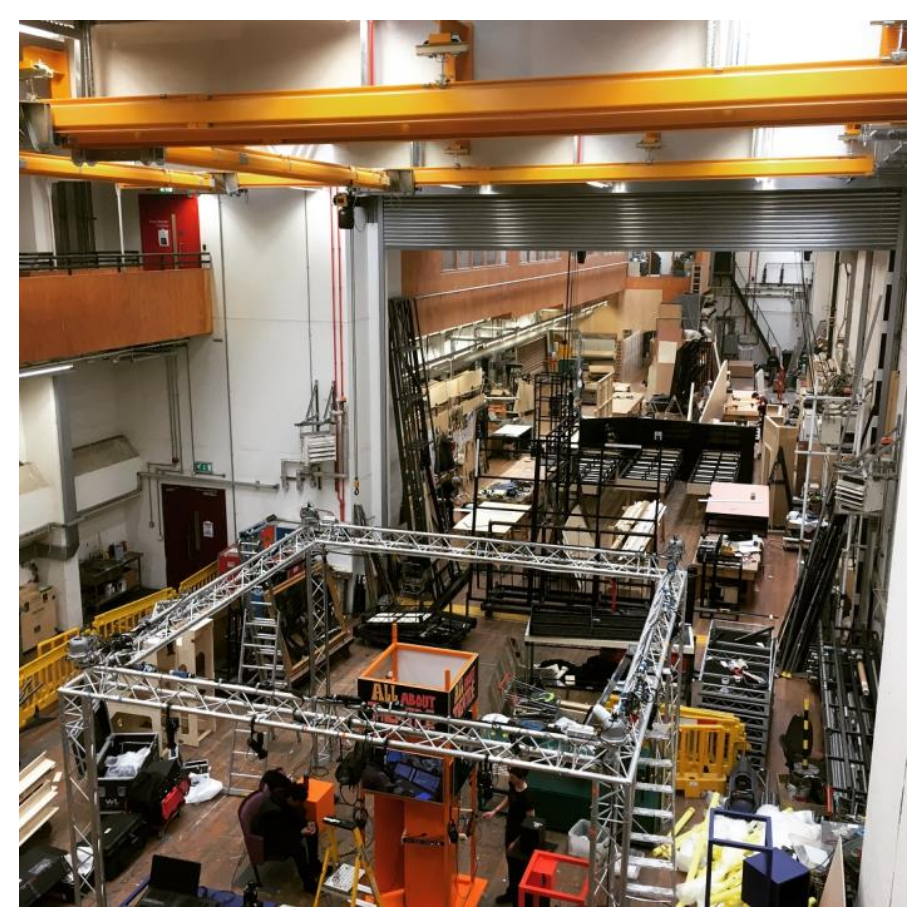

Figure 3 Free Access to Sherling Backstage Walkway [21]

On the elongated terraces that are used as a pedestrian link for outdoor movement on the mezzanines, a pop-up outdoor bar has been created with a fantastic view of this historic part of London. "The strata of the building are like new levels of ground and they will become real places. It is very important that the National Theatre becomes a part of the city. Any idea of a cultural ghetto has gone," said Lasdun [22]. These new levels of the ground create an outdoor space whose features have the traits of the cloister type of form, and is used as a unique space for various themed public and private functions. Lasdun's strata make it hard to define where the National Theatre begins and ends. The interconnected walkways, split levels, and circular stairwells of the South Bank merge with the city itself.

\subsection{Ideological Functions of Space and Architecture}

The National Theatre in London is a complex architectural structure that prides itself on a plethora of ever-evolving functions. Its economic function of aiming to provide art and entertainment for a fee has always been at the core. However, over time, the range of economic functions, as well as the concept itself, has evolved and incorporated elements that are free of charge, and today visitors can enjoy many of these free things. It is a warm, peaceful, and welcoming environment that anyone can use at their leisure, a move that can be viewed as a positive contribution toward maintaining the existing number of visitors, while creating a potential for an increase in numbers. Closely connected with the economic functions nowadays are environmental sustainability functions, where the National Theatre has taken some major steps toward improving its own environmental sustainability.

Through a series of interconnected foyers, an L-shaped main public area is created around the two theaters. Admiration of the National Theatre tends to focus on the magic of these internal spaces, which tower in sections to their full height. It has come to be thought of as one of the city's key communal spaces, described as "the nation's sitting room" [22] and, when viewed from that perspective, it gains complex ambiental functions-a public space that offers an inherently intimate and private experience.

From the urban point of view, this architectural complex has an impressive function, because its public interior spaces merge with the terraces outside, or what Lasdun describes as the geological strata of his architecture of urban landscape, and by doing so, they become part of the urban environment. This effect, in some instances, is barely visible to users who are uninformed regarding the subjects of architecture and urbanism, and it is subtle yet 
Achieving sustainable urbanization of the National Theatre in London through change of use and functions of architecture

undeniable in its occurrence, as a case of an "overspill" of an interior space to the exterior. In other instances, it has high public awareness and visibility, like in the case of the skate park area. The intricate, multi-levelled, external concrete structure has spontaneously attracted a younger population of street sports enthusiasts, in the form of skateboarders, and has gradually become very popular. At first, there was opposition, and a public backlash resulted in a skating ban in this area and the skatepark being relocated. However, once this expulsion occurred, it became evident that skating, with its vibrant subculture, was missing from this urban complex and in the end, it returned. Once again, this architecture changed and embraced new functions that have influenced London's urbanism on a local level.

When addressing key functions of this complex, the esthetic one cannot be missed, with its large scale presentation of concrete as an ever-popular construction material, and horizontal terraces providing a unique stage and backdrop for various theater plays, exhibitions, or concerts, making the scenographic, scenic, theatrical or exhibition function invaluable. Lasdun himself described these spaces as the "our theatre". He said "I feel that all the public areas of the building, the foyers and terraces, are in themselves a theatre with the city as a backdrop [22]". What is also interesting to point out is the ability or the function of this architectural structure to evoke passion, strong opinions, and polarize the public. While some in the media call it "one of London's best-known and most divisive Brutalist buildings"-a layered concrete landscape that Prince Charles once compared to "a nuclear power station", others state that "The National Theatre is one of the last great buildings of the age of public sector architecture." According to architectural historian Kester Ratterbury, "of an ambitious public facility which sought to be itself, not a poor copy of commercial work [22]". In any case, it's impossible to be indifferent toward it.

A great example of a successful and very popular event that continually expands the ideological functions of the National Theatre, is a project called Watch This Space, a quarterly festival of street theater, cabaret, music, and film screenings that takes over the South Bank of the River Thames, primarily in and around the National Theatre. This unique artistic initiative brings together a large number of contemporary artists, who create works live in the external space, under the watchful eye-or at times active participation-of the public. Doing so gives this space and structure new functions, such as cultural, theatrical, poetic, dramaturgical, emotional, inclusive, artistic, promotional, or economic functions.

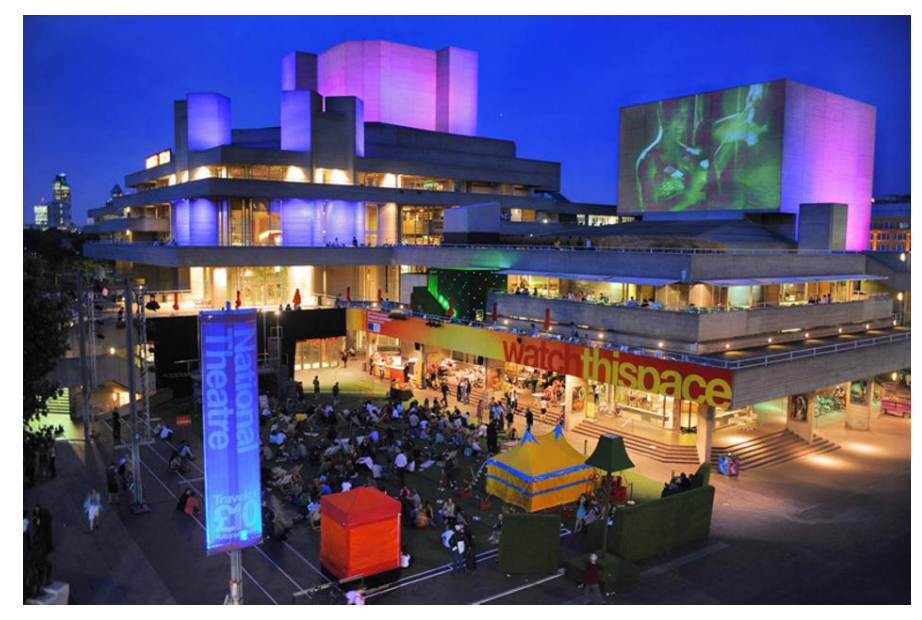

Figure 4 "Watch This Space" - outdoor events at the National Theatre in London [23]

Using the external space around the theatre (initially empty and inert) for such diverse urban community purposes, presents itself as an excellent example of how modern, desirable, and popular functions of architectural and urban form can enrich and repurpose public, urban spaces that were initially envisaged as vacant and, in a sense, negative, into an urban area that becomes a home to a cultural movement, and a permanent part of the city itself. 
Achieving sustainable urbanization of the National Theatre in London through change of use and functions of architecture

\section{KEY ECONOMIC CONCEPTS AND ROLES IN TRANSFORMATIONS OF PUBLIC SPACES AND ARCHITECTURE}

When considering the change of use of space, and the changes and expansion of architectural functions and urban forms from the financial and economic perspective, the process must be carried out at an optimal cost for it to be efficient, easily implemented, and sustainable. In doing so, two concepts that can be extremely effective in achieving such goals and which may not be used enough nowadays, must be taken into consideration.

\subsection{Recycling of Uses and Functions of Architecture and Public Spaces}

Recycling, in simple terms, is a process that involves the conversion of materials and products into new products of lower quality, due to the reduction of the quality of the original product or materials during the production process [24]. Recycling has different aspects and ways of implementation, but when viewed in terms of uses and functions, and the new uses of the emergent products, one of its key features is a positive contribution to innovation, as well as savings with regard to the creation of new urban spaces. The original uses of a specific public space can be changed and adapted to the new needs of a community, as already seen in the case of the National Theatre in London. Hence, instead of completely deconstructing, clearing the previously created public space, it is possibleutilizing the principles of recycling - to use some of the original elements to meet the new needs and requirements of any given space or structure. This process should also include elements of innovation, to achieve the best possible results, as well as keep up with the present era. Thus, to recycle the space, the recycling of its physical elements should be done first and, by doing so, financial, urbanistic, and social benefits can be achieved.

Furthermore, according to Molineux et al. [25], when striving to use the principles of recycling, contribution toward the reduction of waste and reducing refurbishment costs are simultaneously achieved. For example, if a green roof is created on top of a conventional building, presently out of public use, a certain range of benefits associated with the installation of $\mathrm{Gl}$ is achieved, while the space has simultaneously been repurposed and upgraded in terms of the social, environmental, inclusive or rural functions of the original architecture. Therefore, in addition to the positive contribution of recycling as a tool for increasing $\mathrm{GI}$ (with savings), it can also be used for the repurposing of the architectural functions of public and urban spaces, especially brown-field locations, where it can revitalize the entire urban area with minimum investment. At the same time, discarded urban infrastructure, inventory, and "waste" materials can be reused or recycled for new purposes. A great example of this is the originally unused area around the National Theatre that has nowadays become a popular and iconic skateboarding space. These initial reservoirs of technosphere resources, as Williams calls them [26], offer an excellent opportunity for and contribution to sustainable development, as they provide a significant reduction in the financial investment required for sustainable urbanization.

\subsection{Upcycling of Uses and Functions of Public Spaces and Architecture}

The term upcycling is quite recent and was officially entered in the Oxford Dictionary in 2014, meaning: "Work or process of reusing waste materials to create products of greater value or quality". Upcycling was originally used by recycling pioneer Reiner Pilz, a mechanical engineer from Germany, in 1979, who in an interview [27] talked about the use of antiques and materials, after restoring them and then using them as objects of greater value, thereby increasing their initial value. Upcycling is a concept that is still insufficiently established and it is considered to be one of the most sustainable, cyclical, economical solutions, located between reuse and recycling. Upcycling typically requires minor energy and resource input, and can eliminate the need for a new, more expensive product [14]. This principle can also be applied to creating new public spaces and functions of architecture and urban forms. "People have negative impressions of vacant land and use different terms to describe them, such as abandonment, decay, emptiness and in some instances even danger" [28., p.1]. Abandoned spaces are at times unpleasant and contribute to the negative aspects of the urban areas; they are capital waiting to be re-evaluated and reclaimed. In 1971, Ray Northam, an urban economist, classified vacant land in American cities into five somewhat mutually exclusive types: remnant parcels, parcels with physical limitations, corporate reserve parcels, parcels held for speculation, and institution reserve parcels [28].

Rogina, D, Dinulović, $R$ 
Achieving sustainable urbanization of the National Theatre in London through change of use and functions of architecture

For example, a space originally planned to be utilized as a parking area, can be used-following the closure of the establishment-as an urban garden with raised beds, or as an area for small street festivals. Also, a space planned initially as a walkaway, can be later used as a café terrace or a theater stage, as demonstrated in the example of the National Gallery in London's outdoor events. From the point of view of upcycling, professionals should explore ways to create places of increased quality, additional functions, and significance, making only necessary changes that would require optimal amounts of new resources, while preserving Rossi's collective memory of the city and identity. To achieve this, it is necessary to make careful studies of the existing possibilities and potentials of urban places. The recycled spaces that are systematically planned and envisaged within the lowbudget design, should also be multifunctional, while providing the local population with various services ranging from urban to ecosystem-related domains. The goal of such a process should be to create synergies that increase the influence of the overall benefits provided by urbanization, including elements of GI [14].

In conclusion, recycling and upcycling are two relatively new concepts, especially concerning the implementation of the change of use or function of a space. They are particularly useful elements of efficiency and frugality because they represent a valuable link in the chain of a circular/cyclical economy [26]. This makes them important and valuable tools, due to the ability to reuse and enrich urban spaces with new uses and functions, and thereby positively contribute toward the future of sustainable urbanization, both globally and locally.

\subsection{The Role of the Individual and the Community in the Creation of a Sustainable Urban Environment}

If architecture and urban forms are considered from a perspective that regards the main preoccupation of architecture as human life and not the built environment [4], then the focus shifts to personal responsibility, and architecture advocates must direct energy toward the built world and subsequently urban environment, which will improve the quality of human life. From this perspective, architecture becomes a tool that can help us overcome the contradictions and crises emerging from other parts of (capitalist) society [29]. Individual responsibility becomes fundamental, so does the right to an individual view of the world, restoring our self-confidence, giving us back our spaces, and recognizing our continuity.

Calvino, in his book 'Invisible Cities' [30], while describing the ideal city of Fedora and the attitude of an individual inhabitant toward it, speaks of all possible cities being created in glass spheres. "In every period, looking at the existing Fedora, one imagined how to make it an ideal city, but even while he was assembling its model in miniature, Fedora was no longer the one it was before and its possible future until yesterday became just a model under the glass dome. In the building with glass domes, Fedora now has its museum: every citizen visits it, chooses a city that suits his wishes, imagines it imagining himself looking at a pond with jellyfish that was supposed to collect water from the canal (if it had not been drained), from a height the canopy overflows an alley intended for elephants (now expelled from the city), as it descends the winding stairs of the minaret (now with no ground on which to be constructed)." Calvino (in 'Invisible Cities') says that all these realities and concepts need to find their place, not because they are all equally valid or real, but because they are equally assumed, and this can also be applicable to individuals, who therefore take ownership of and responsibility for the city's space, with its content and functions.

Lefebvre stated that the right to the city, complemented by the right to difference and the right to information, should modify, concretize, and make more practical the rights of the citizen as an urban dweller (citadin) and user of multiple services [31]. This further affirms the right of users to declare their ideas about the space in the urban area. All stakeholders in an urban area should be able to negotiate for their "right to the city" [32] and by doing so, actively benefit from urban living, through the improved access of all marginalized groups, including the elderly.

Developing Lefebvre's concept, Harvey [33] argues that the right to the city goes beyond the license of an individual to access its resources; it is a right to change ourselves by changing the city, "involving the exercise of a collective power to reshape the processes of urbanization" [33]. Rossi [2] speaks of places that history has predetermined, and which are the real signs of space and, as such, have a relationship with a chance, heritage, and tradition. According to him, the idea of a locus is at the same time an idea of both space and time, and it includes those special places that are identified by something that had happened occurred in them. In doing so, the individual has the power to reach for the disappearing contours of the spaces and create some new ones based on the solid foundations of the past. That gives the individual an opportunity as well as the power to participate actively in the transformation of his or her environment, in myriad ways. This opportunity is particularly plausible in the 21 st century, because this is a time of media influencers, when digitization, computerization, and mass access

Rogina, D, Dinulović, $R$ 
Achieving sustainable urbanization of the National Theatre in London through change of use and functions of architecture

to the Internet has led us to the phenomenon of the great influence of the individual on the multitude, both locally and globally. By recycling or upcycling urban spaces and carrying out various activities, such as, "Watch This Space at National Theatre", an individual or a group can create a variety of new functions, some of which could be: gardening and food production: by installing urban gardens and green roofs; tourism and recreation: by converting deserted, neglected and abandoned riverside into multifunctional beaches; ecological: by creating recycling sites in unused or neglected sites; or entrepreneurial: by creating common work-place spaces as incubators of new ideas and concepts. In this way, in addition to the two concepts already mentioned, an individual can also learn a lot from the frugal architecture of slums, which emerged more out of necessity than choice, but was created with great awareness of resource constraints nonetheless, and is therefore extremely relevant as an element of sustainable urbanization. All these concepts can be valuable tools for the individual to cope with various urban challenges [14]. Only in those cities where local authorities work together with citizens and which transparently accept the participation of the community, the best possible results and the most optimal, multifunctional urban environments created with minimal difficulties in terms of implementation and sustainability can be achieved. Tensions and issues that inevitably arise between social and ecological systems [34], such as issues with regard to managing various resources or new/old functions, should be accepted and included in the community, to achieve the best results. Only in that way will a further increase in sustainability, innovation, cost reduction, and several desirable functions of urban spaces occur, proving the success of bottom-up approaches in everyday practices.

\section{CONCLUSIONS}

This paper has established that the change of use of public space and urban forms, as well as their functions, are a valuable tool for achieving sustainable urbanization, with an individual in the power-position of a change initiator. It illustrated how an urban form with an originally clear and specific concept of architectural utilitarian use and ideological functions, such as the National Theatre in London, can gradually evolve into something that not only enriches the identity of an area, but also evolves itself through its ability to provide additional functions and uses for various urban stakeholders. In this manner, advancing with time positively and sustainably contributes toward the new identity of the urban area. However, for such change to be most optimal-and as far as possible-"tailormade" for the local community, it is necessary to include as many stakeholders as possible. They will establish the specific functions, uses, and needs that will result in the best possible sustainable urban environment, while simultaneously enabling an individual to establish their true right to the city. For that to happen in any given urban environment, further research is required, which should include urban dwellers, experts, local authority figures, and representatives of as many stakeholders as possible. Following this research and data collection, a database would be produced, serving as an inherent foundation on which the most optimal urban spaces would be created, through the implementation of determined urban and architectural uses and functions.

\section{References}

[1] Sharma, S. N. 2014: Urban forms in planning and design, International Journal of Research, 1 (1), pp. 7-16.

[2] Rossi, A. 1982: The Architecture of the City, Opposition books, MIT, Massatccussess, USA.

[3] Crawford, M. 1991: 'Can Architects Be Socially Responsible?, In Out of Site: A Social Criticism of Architecture, Ghirardo, D. (Ed.), Bay Press, Seattle, USA, pp. 27-45.

[4] Dinulović, R. 2014: The Ideological Function of Architecture in the Society of Spectacle; in Architecture and Ideology; Mako, V.; Roter Blagojević, M.; Vukotić Lazar, M. (Eds.); Cambridge Scholar Publishing, pp. 42-50.

[5] Yin, R. K. 2014: Case Study Research Design and Methods, 5th Edition, Sage Publication.

[6] Ward, A. 1996: The Suppression of the Social in Design: Architecture as War', in: Dutton, T. A.; Mann, L.H. (eds), Reconstructing Architecture: Critical Discourses and Social Practices, Minneapolis: University of Minnesota Press, pp. 27-70.

[7] Rossi, A.; Consolascio, E.; Reichlin, B.; Reinhart, B. 1976. The Analogous City, Venice Biennale of Architecture, Venice, Italy.

[8] Yates, A. F.: The Art of Memory (2001) Paperback, The University of Chicago Press, Chicago.

Rogina, D, Dinulović, $R$ 
Achieving sustainable urbanization of the National Theatre in London through change of use and functions of architecture

[9] United Nations, Department of Economic and Social Affairs, Population Division 2019: World Urbanization Prospects 2018: Highlights, United Nations, New York, USA.

[10] Asimov, I. 1977: Pod čeličnim nebom, Beograd, Jugoslavija. [in Serbian]

[11] Lang, J. 1994: Urban Design: The American Experience, Van Nostrand Reinhold, New York, USA.

[12] Votinov, M.; Smirnova, O. 2019: Eco-oriented architecture as a means of creating a sustainable urban environment, Electronic Journal of the Faculty of Civil Engineering Osijek-e-GFOS, 10 (18), pp. 1-11. https://doi.org/10.13167/2019.18.1

[13] European Environment Agency, EEA Technical report No 18/2011: Green Infrastructure and Territorial Cohesion, 2011, Publications Office of the European Union, Luxembourg.

[14] Herman, K.; Sbarcea, M.; Panagopoulos, T. 2018: Creating Green Space Sustainability through Low-Budget and Upcycling Strategies, Sustainability, 10 (6), 1857. https://doi.org/10.3390/su10061857

[15] Nabielek, K. 2016: Cities in Europe, PBL Netherlands Environmental Assessment Agency, The Hague, Netherlands.

[16] Camaren, P.; Swilling, M. 2012: Sustainable Resource Efficient Cities: Making It Happen, UNEP: Nairobi, Kenya.

[17] McGill University 2008: What is Urban Planning?, School of Urban Planning, McGill University, Canada. https://www.mcgill.ca/urbanplanning/planning, Accessed 12 November 2020

[18] Ziehl, M.; Oßwald, S. 2015: Practices in second-hand spaces: Producing value from vacancy, Ephemera, 15 (1), pp. 263-277.

[19] Lopez-Marcos, M. 2018: Inhabiting leftovers - Architectural incursions in negative space, IDEA JOURNAL Dark Space_the interior, 16 (1), pp. 148-162. https://doi.org/10.37113/ideaj.vi0.21

[20] Theatre London, https://www.nationaltheatre.org.uk/about-the-national-theatre/careers , Accessed 7 December 2021

[21] Secret London, https://secretldn.com/sherling-backstage-walkwayl, Accessed 21 September 2021

[22] Mull, O. 2014: Brutalist buildings: National Theatre, London by Denys Lasdun, https://www.dezeen.com/2014/10/06/brutalist-buildings-national-theatre-london-denys-lasdun/, Accessed 24 February 2021

[23] Exeunt magazine, http://exeuntmagazine.com/features/rufus-norris-national-theatre/, Accessed 21 September 2021

[24] Environmental Protection Agency (EPA) 2018: Recycling: Protecting the Environment. https://www.epa.gov/recycle, Accessed 12 November 2020

[25] Molineux, C.J.; Gange, A.C.; Connop, S.P.; Newport, D.J. 2015: Using recycled aggregates in green roof substrates for plant diversity, Ecological Engineering, 82, pp. 596-604. https://doi.org/10.1016/i.ecoleng.2015.05.036

[26] Williams, J. 2019: Circular Cities: Challenges to Implementing Looping Actions, Sustainability, 11 (2), 423. https://doi.org/10.3390/su11020423

[27] Kay, T. 1994: Salvo in Germany-Reiner Pilz, p14 SalvoNEWS No. 99, 11 October 1994.

[28] Bowman, A. O'M.; Pagano, M. A. 2004: Terra incognita: vacant land and urban strategies, Georgetown University Press, Washington, USA.

[29] Jones, P.; Card, K. 2011: Constructing "Social Architecture": The Politics of Representing Practice, Architectural Theory Review, 16 (3), pp. 228-244. https://doi.org/10.1080/13264826.2011.621543

[30] Calvino I. 1998: Nevidljivi gradovi, Džepna Ceres, Zagreb, Croatia. [in Croatian]

[31] Lefebvre, H. 2000: Writing on Cities, Blackwell Publisher Ltd., Oxford, UK.

[32] Lefebvre, H. 1991: The social production of space, Blackwell Publisher Ltd., Oxford, UK.

[33] Harvey, D. 2008: The right to the city, New Left Review, 53, pp. 23-40

[34] Diep, L.; Dodman, D.; Parikh, P. 2019: Green infrastructure in informal settlements through a multiple level perspective, Water Alternatives, 12 (2), pp. 554-570.

Please cite this article as: Rogina, D., Dinulović, R.: Achieving sustainable urbanization of the National Theatre in London through change of use and functions of architecture, Electronic Journal of the Faculty of Civil Engineering Osijek-e-GFOS, 2021, 23, pp. 11-21, https://doi.org/10.13167/2021.23.2

Rogina, D, Dinulović, $R$ 